\title{
Interaction of Portland cement hydration products with complex chemical additives containing fiberglass in moisture-proof cement compositions
}

\author{
O.I.Demina ${ }^{1}$, A.A.Plugin ${ }^{2}$, E.B.Dedenyova ${ }^{1}$, \\ D.A.Bondarenko ${ }^{1}$, T.A.Kostuk ${ }^{1}$, A.I.Bondarenko ${ }^{1}$ \\ ${ }^{1}$ Kharkiv National University of Civil Engineering and Architecture, \\ 40 Sumskaya Str., 61002 Kharkiv, Ukraine \\ ${ }^{2}$ Ukrainian State University of Railway Transport, 7 Feuerbach Sq., 61050 \\ Kharkov, Ukraine
}

Received March 17, 2017 Physicochemical studies of interaction of the hydration products of Portland cement with
the complex chemical additives, which ensure the penetrating action of moisture-proof cement
compositions with the borosilicate fiberglass, have been executed. It is established that the
fiberglass tightly outgrows by such products of hydration as crystal hydrates and hydrosili-
cate gel, and durable electro-heterogeneous contacts are formed between them. It is established
that one can not expect the destruction of the fiberglass in the alkaline medium of concrete
block in view of the dense structure of the hydration products of. With the development of
the moisture-proof cement compositions containing fiberglass it is recommended to give the
preference to calcium salts, minimizing the content of sodium salts.

Keywords: Portland cement, additives, fiberglass, hydration, crystal hydrates.

Выполнены физико-химические исследования взаимодействия продуктов гидратации портландцемента с комплексными химическими добавками, обеспечивающими проникающее действие гидроизоляционных цементных композиций, с боросиликатным стекловолокном. Установлено, что стекловолокно плотно обрастает продуктами гидратации - кристаллогидратами и гидросиликатным гелем, между ними образуются прочные әлектрогетерогенные контакты. Установлено, что ввиду плотной структуры продуктов гидратации разрушения стекловолокна в щелочной среде цементного камня ожидать не следует. При разработке состава гидроизоляционных цементных композиций со стекловолокном рекомендовано отдавать предпочтение кальциевым солям, минимизируя содержание натриевых солей.

Взасмодія продуктів гідратації портландцементу з комплексними хімічними добавками зі скловолокном у гідроізоляційних цементних композиціях. О.І.Дьоліна, А.А.Плугін, Є.Б.Деденьова, Д.А.Бондаренко, Т.А.Костюк, А.І.Бондаренко.

Виконано фізико-хімічні дослідження взаємодії продуктів гідратації портландцементу з комплексними хімічними добавками, що забезпечують проникаючу дію гідроізоляційних цементних композицій з боросилікатним скловолокном. Встановлено, що скловолокно щільно обростає продуктами гідратації - кристалогідратами і гідросілікатним гелем, між ними утворюються міцні електрогетерогенні контакти. Встановлено, що 3 огляду на щільну структуру продуктів гідратації руйнування скловолокна у лужному середовищі цементного каменю очікувати не слід. При розробці складу гідроізоляційних цементних композицій зі скловолокном рекомендовано надавати перевагу кальцієвим солям, мінімізуючи вміст натрієвих солей. 


\section{Introduction}

At present in construction practice the moisture-proof cement compositions of penetrating action become more popular. They are cement-sand dry mixtures with the complex chemical additive (CCA), closed by water and applied to the preliminarily moistened concrete surface of hydro-isolated (during construction or repair works) buildings and structures. Having hardened, the composition forms impermeable coating, and dissolved minerals of cement and CCA components diffuse into the concrete surface layer and are crystallized in its pore space, packing it and creating the additional impermeable barrier [1]. The possibility of waterproofing structures from the side of the surfaces ensures special practical value to compositions, which are undergone by socalled "negative" hydrostatic pressure of the underground structures' internal surfaces and basement premises, downstream faces of hydraulic engineering structures, etc.

However, the compositions possess such drawbacks as the narrow range of applicability owing to the material of isolated structure and temperature, tendency toward the formation of decreasing the impenetrability of coating cracks after shrinkage, mechanical and vibration actions, high cost because of the high costs of CCA components, application of the pure Portland cement 7 and washed fractionated fillers.

At present there are CCA compositions, which include chlorides, nitrates, sulfates, carbonates, hydroxides of calcium and/or sodium, etc [2]. It is established that GSAK, GCHAK, GNAK, GKAK, GOCHK calcite can be crystalline products of the cement hydration, making alluvial pore space, depending on combination of the indicated reagents and hardening conditions, (arbitrary symbols are accepted on and are given in Tabl.), which agree with the data $[2,3]$. The interaction analysis of crystal hydrates with the surfaces of fillers, fibers, holes, was carried out on the basis of ideas about the cement stone and compositions as the poly-disperse materials, determining their physicomechanical and hydrophysical properties by surface electric charges and electro-surface potentials of the products of hydration, fillers, fibers, and also by the nature of contacts between them [4]. Designation of the CCA compositions and mixtures was carried out from guarantee of a maximum quantity of electro-heterogeneous contacts in the structure (between elements with the surface charges opposite in the sign), providing the physicomechanical properties.

It is known that fiberglass in the alkaline medium of concrete block $(\mathrm{pH} \sim 12,5)$ unstably and gradually loses strength due to dissolution. It is shown in [5] that even during the dissolution of fibers their structuring action on the hydration products of cement with CCA (isotropic micro-reinforcement by hydration products) causes an improvement in the physicomechanical indices of the composition. However, action of the medium of concrete block with CCA to the fiberglass remains insufficiently studied.

The purpose of the present investigation is refinement of the nature of interaction between the hydration products of the Portland cement with CCA and reinforcing the fiberglass and development of recommendations regarding the minimization of destructive action on the fiber.

\section{Experimental}

There was an investigation of composition on the basis of Portland cement PC II SH-400DSTU B V.2.7-46 (analogCEM II/AS32,5 EN 197), of quartz sand DSTU B Of v.2.7-32, CCA, which includes chlorides, nitrates, sulfates, carbonates, hydroxides of calcium and/or sodium, boro silicate fibre glass with diameter of $3-100 \mathrm{~m}$, length of $2-3 \mathrm{~mm}$, density of $2480 \mathrm{~kg} / \mathrm{m}^{3}$, and tensile strength of $3.5 \mathrm{hPa}$.

Composition of hydration products of the Portland cement with CCA was investigated using independent physicochemical methods: X-ray phase and differential thermal analysis. The tests of concrete block selected from the composition models after 28 the twenty-four hours of hardening, separating them thoroughly from the particles of the quartz sand. X-ray photographs were written by computerized X-ray diffractometer DRON-3 with a X-ray tube $1,6 \mathrm{BSV} 27-\mathrm{Fe}$ and software DifWin1 in the interval of angles $2 \theta=7-80$ (under stress of $30 \mathrm{kV}$ with the current strength $20 \mathrm{~mA}$. Thermograms were written using instrument Derivatograph Q-1500 with the weights' sensitivity of $1200 / 1000$, DTA $1 / 10$, DTG $1 / 10$, a platinum holder, conducting heating with rising of temperature by $10^{\circ} \mathrm{C} / \mathrm{min}$ to $1000^{\circ} \mathrm{C}$. For the identification of the minerals and products of hydration their most characteristic diffraction peaks and endoeffects were used according to the data [6].

The nature of interaction between the hydration products of cement with CCA and fiberglass was investigated during chip- 
Table. Conventional representations of the minerals of Portland-cement clinker and products of the Portland cement hydration

\begin{tabular}{|c|c|c|}
\hline Representation & Designation and chemical composition & $\begin{array}{l}\text { Minerals, hydration } \\
\text { products }\end{array}$ \\
\hline $\mathrm{C}_{3} \mathrm{~S}$ & Tricalciumaluminate $3 \mathrm{CaO} \cdot \mathrm{SiO}_{2}$ & \multirow{4}{*}{$\begin{array}{l}\text { Minerals of Portland } \\
\text { cement clinker }\end{array}$} \\
\hline $\mathrm{C}_{3} \mathrm{~S}$ & Dicalciumaluminate $2 \mathrm{CaO} \cdot \mathrm{SiO}_{2}$ & \\
\hline $\mathrm{C}_{3} \mathrm{~A}$ & Tricalciumaluminate $3 \mathrm{CaO} \cdot \mathrm{Al}_{2} \mathrm{O}_{3}$ & \\
\hline $\mathrm{C}_{4} \mathrm{AF}$ & Four-calcium alumo-ferrite $3 \mathrm{CaO} \cdot \mathrm{Al}_{2} \mathrm{O}_{3} \cdot \mathrm{Fe}_{2} \mathrm{O}_{3}$ & \\
\hline $\mathrm{CH}$ & Hydroxide of calcium (portlandite) $\mathrm{Ca}(\mathrm{OH})_{2}$ & \multirow{7}{*}{$\begin{array}{l}\text { Products of Portland } \\
\text { cement hydration }\end{array}$} \\
\hline $\mathrm{C}_{2} \mathrm{SH}$ & $\begin{array}{l}\text { Highly basic hydrosilicates of calcium } \\
\qquad(1.5-2) \mathrm{CaO} \cdot \mathrm{SiO}_{2} \cdot(1.5-2) \mathrm{H}_{2} \mathrm{O}\end{array}$ & \\
\hline $\mathrm{CSH}$ & $\begin{array}{l}\text { Low basic hydrosilicates of calcium } \\
(0.8-1.5) \mathrm{CaO} \cdot \mathrm{SiO}_{2} \cdot(0.5-2.5) \mathrm{H}_{2} \mathrm{O}\end{array}$ & \\
\hline $\mathrm{CAH}_{10}$ & Decahydrate hydro-aluminate of calcium $\mathrm{CaO} \cdot \mathrm{Al}_{2} \mathrm{O}_{3} \cdot 10 \mathrm{H}_{2} \mathrm{O}$ & \\
\hline $\mathrm{C}_{3} \mathrm{AH}_{6}$ & Hexahydrate hydro-aluminate of calcium $3 \mathrm{CaO} \cdot \mathrm{Al}_{2} \mathrm{O}_{3} \cdot 6 \mathrm{H}_{2} \mathrm{O}$ & \\
\hline GSAK-3 & $\begin{array}{l}\text { Hydro-sulf aluminate of calcium of three-sulfate form } \\
\text { (ettringite) } 3 \mathrm{CaO} \cdot \mathrm{Al}_{2} \mathrm{O}_{3} \cdot 3 \mathrm{CaSO}_{4} \cdot 32 \mathrm{H}_{2} \mathrm{O}\end{array}$ & \\
\hline GSAK-1 & $\begin{array}{l}\text { Hydro-sulf aluminate of calcium of mono-sulfate form } \\
\qquad 3 \mathrm{CaO} \cdot \mathrm{Al}_{2} \mathrm{O}_{3} \cdot \mathrm{CaSO}_{4} \cdot 10 \mathrm{H}_{2} \mathrm{O}\end{array}$ & \\
\hline GKAK-3 & $\begin{array}{l}\text { Hydro-carboaluminate of calcium of three-carbonate form } \\
\qquad 3 \mathrm{CaO} \cdot \mathrm{Al}_{2} \mathrm{O}_{3} \cdot 3 \mathrm{CaCO}_{3} \cdot 32 \mathrm{H}_{2} \mathrm{O}\end{array}$ & \multirow{6}{*}{$\begin{array}{l}\text { Products of CCA } \\
\text { Portland cement } \\
\text { hydration }\end{array}$} \\
\hline GKAK-1 & $\begin{array}{l}\text { Hydro-carboaluminate of calcium of mono-carbonate form } \\
\qquad 3 \mathrm{CaO} \cdot \mathrm{Al}_{2} \mathrm{O}_{3} \cdot \mathrm{CaCO}_{3} \cdot 12 \mathrm{H}_{2} \mathrm{O}\end{array}$ & \\
\hline GCHAK & Hydro-chloralminAT of calcium $3 \mathrm{CaO} \cdot \mathrm{Al}_{2} \mathrm{O}_{3} \cdot \mathrm{CaCl}_{2} \cdot 10 \mathrm{H}_{2} \mathrm{O}$ & \\
\hline GNAK & Hydro-nitroaluminate of calcium $3 \mathrm{CaO} \cdot \mathrm{Al}_{2} \mathrm{O}_{3} \cdot \mathrm{Ca}\left(\mathrm{NO}_{3}\right)_{2} \cdot 10 \mathrm{H}_{2} \mathrm{O}$ & \\
\hline GOCHK & Hydro-oxychloride of calcium $3 \mathrm{Ca}(\mathrm{OH})_{2} \cdot \mathrm{CaCl}_{2} \cdot 12 \mathrm{H}_{2} \mathrm{O}$ & \\
\hline calcite & calcite $\mathrm{CaCO}_{3}$ & \\
\hline
\end{tabular}

pings of the composition through 7, 14 and 28 the twenty-four hours of hardening using scanning electron microscope JEOL JSM-840. Survey was conducted under the power of $5 \mathrm{kV}$ with increase $\times 1000-4000$.

\section{Results and discussion}

As a result of the X-ray phase analysis (with respect to change in the intensity values of diffraction peaks) it is established that after introduction of CCA the degree of hydration of $\mathrm{C}_{3} \mathrm{~S}$ and $\mathrm{C}_{2} \mathrm{~S}$ (intensity 2.73; $2.62 \AA$ ) changes unessential, $\mathrm{CH}$ quantity $(2.62 ; 1.92 \AA)$ and GSAK $(9.73 ; 8.9 \AA)$ does not increase, but a total quantity of $\mathrm{S}_{2} \mathrm{SH}$ and CSH $(3.28,3.04,2.42,1.82 \AA)$ decreases. The degree of hydration of $\mathrm{C}_{3} \mathrm{~A}$ and $\mathrm{C}_{4} \mathrm{AF}$ (7.3 and 2.69 $\AA$ ) substantially rises up to their practically total hydration; $\mathrm{CAH}_{10}$ (14.1; 7.19; 2.28; 2.9), GCHAK, GNAK, GKAK, GOCHK $(9.4 ; 8.7 ; 8.4 ; 7.91 ; 7.6$; $4.35 ; 3.94)$, the calcite $(2.49 ; 2.28 ; 2.09$; 1.87) are formed.
As a result of the differential thermal analysis (with respect to change in the intensity of special enodoeffects) it is confirmed that quantity of $\mathrm{CH}$ (intensity (-) 620 (s) changes unessential, the total quantity of $\mathrm{S}_{2} \mathrm{SH}$ and $\mathrm{CSH}(160-170 ; 490 ; 620$; $800 ; 830$ (s) does not increase, but the base strength of the hydrosilicates of calcium is reduced; $\mathrm{CSH}$ quantity $(800 ; 830$ (s) increases, GCHAK $(800 ; 830)$, GKAK, the calcite (860) are formed.

Fig. 1 shows the electron-microscopic photographs of chippings of the cement composition with CCA and fiberglass through 7, 14 and 28 the twenty-four hours of hardening. From Fig. 1 it is evident that the fiberglass tightly outgrows by such hydration products as crystals of various forms, which form the unique "cartridge clip", with the volume of 3-5 times more than the volume of fiber. Accumulations of the hydrosilicate gel in the form of fishscales, plates, needle-shaped adhesions $\left(\mathrm{S}_{2} \mathrm{SH}\right.$, SSH) are visible between the crystals. 


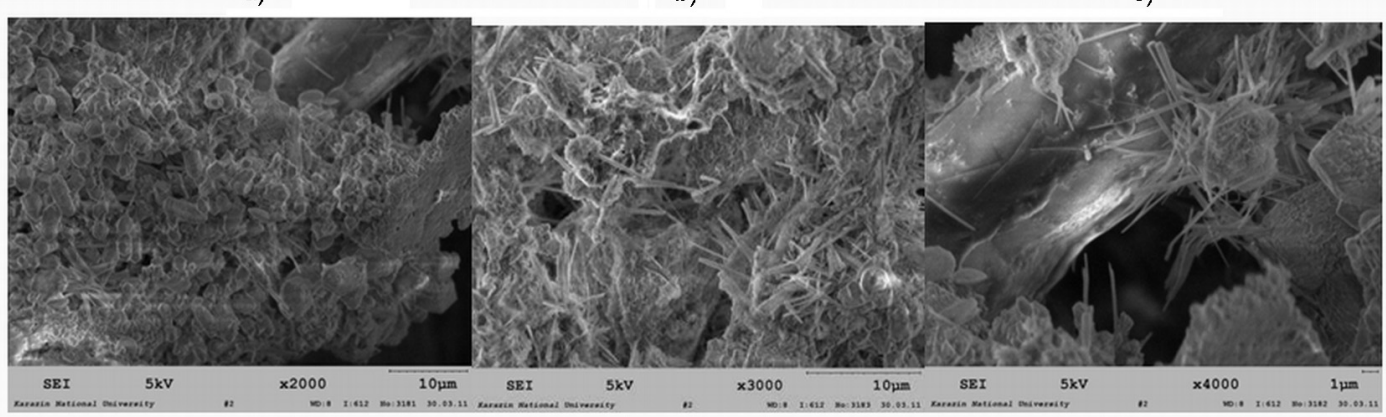

d)

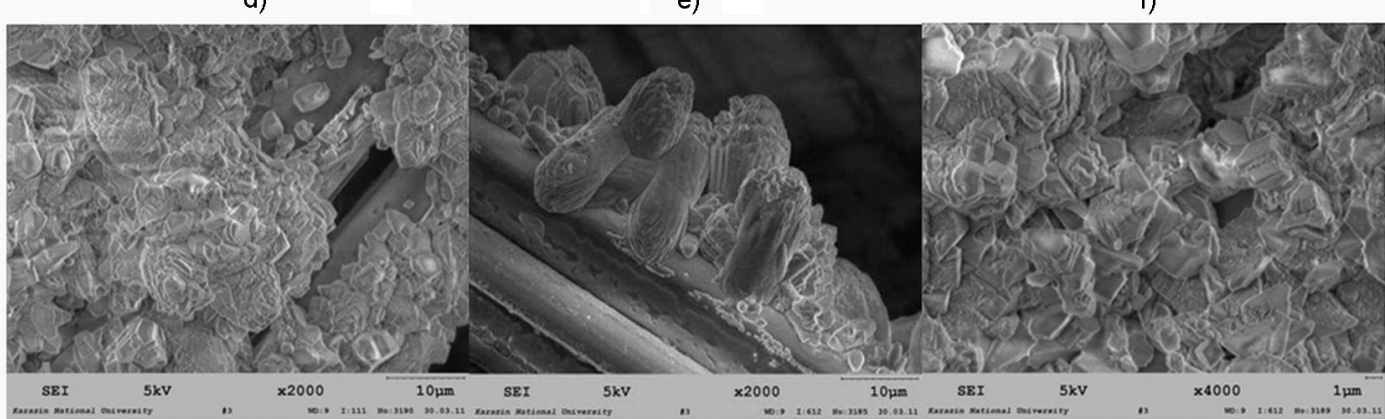

g)

h)

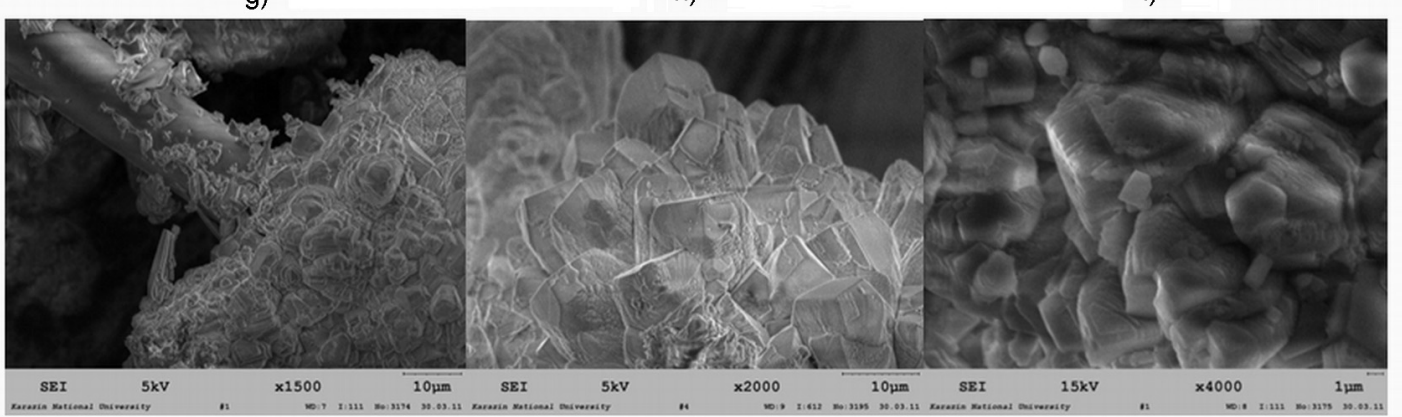

Fig. 1 Electron-microscopic images of chips of cement composition with CCA and glass fiber through $7(\mathrm{a}-\mathrm{c}), 14(\mathrm{~d}-\mathrm{f})$ and $28(\mathrm{~g}-\mathrm{i}) 24$-hours of hardening. $\times 1500-4000$.

At age of 7 twenty-four hours in the composition of the crystalline products of hydration the acicular crystals by length to $5 \mu \mathrm{m}$ (Fig.1b, c), characteristic for GSAK-3, the hexagonal plates, characteristic for GKHAK and GKAK are noted.

Within the later periods of the hardening during 14-28 of twenty-four hours (Fig. 1, g- and) the crystals are noted: hexagonal, which are characteristic for $\mathrm{CH}$, GSAK-1, GCHAK, GKAK, cubic, which are characteristic for $\mathrm{CAH}_{10}$, in the form of the rhombohedral prisms, which are characteristic for the calcite. In the age of 14 twenty-four hours the prismatic dendrites of three-dimensional structure (Fig.1d) characteristic for $\mathrm{CAH}_{10}$ are noted. From the hydration products around the fibers it thickens with the time "cartridge clip", it becomes denser, separate crystals in it become more largely. Thus, the sizes of calcite crystals at the age from 14 to 28 of twentyfour hours increase from 2 (Fig.1e) to $10 \mu \mathrm{m}$ (Fig.1z, and).

Taking into consideration the fact that the crystals of CH, GSAK, GCHAK, GNAK, GKAK, calcite are characterized by positive surface charge, and the hydrosilicates of calcium $\mathrm{S}_{2} \mathrm{SH}$, SSH fiberglass by the negative ones [5], the durable electro-heterogeneous contacts are formed between the fiberglass and the crystals, and also between the crystals and hydrosilicates of calcium. Due to the dense structure of the hydration products, by which the fiberglass outgrows to the age of 14-28 twenty-four hours, the fiberglass destruction in alkaline medium of concrete block can not be expected. How- 
ever, for averting the destructive action of the medium of concrete block on the fiberglass it is recommended additionally to give the preference to calcium salts with the designation of CCA composition, minimizing the content of sodium salts.

\section{Conclusions}

As the studies result, the nature of interaction of the Portland cement hydration products with CCA, including chlorides, nitrates, sulfates, carbonates, calcium and / or sodium hydroxides, with reinforcing borosilicate fiberglass was clarified.

It is established that the glass fiber is densely overgrown by the products of hydration - crystals of CH, SAN10, GSAK, GCHAK, GNAK, GKAK, calcite of various shapes, forming the kind of "holder", whose volume is $3-5$ times more than the fiber volume. There are particles of hydrosilicate gel $\mathrm{C}_{2} \mathrm{SH}$, CSH between the crystals.

Between the glass fiber and the crystals, as well as between the crystals and calcium hydrosilicates, the strong electroheterogeneous contacts are formed. Due to the dense structure of the hydration products that the glass fibers accumulate, the destruction of fiberglass in alkaline cement stone environment should not be expected.
When developing the composition of CCA for the compositions containing glass fibers, it is recommended to give preference to calcium salts to minimize the destructive effect of the cement stone environment on it, minimizing the content of sodium salts.

\section{References}

1. D.O.Bondarenko, R.A.Yakovleva, T.O.Kostiuk, O.Yu.Proshin, 30th SAMPE Eur. Intern. Jubilee Conf., Paris, France (2009), p.563.

2. M.G.Saliya, T.A.Kostyuk, Yu.A.Spirin, A.A.Plugin, Physicochemical Studies of Cement Stone with Chemical and Mineral Additives, Increasing Crack Resistance and Waterproofness, UkrDAZT, Kharkiv, Ukraine (2012).

3. M.Balonis, M.Mkdala, F.P.Glasser, Adv.Cem. Res., 23, (2011).

4. A.N.Plugin, A.A.Plugin, O.A.Kalinin, Fundamentals of the Theory of Hardening, Strength, Destruction and Durability of Portland Cement, Concrete and Structures of Them, Naukova Dumka, Kyiv, Ukraine (2012).

5. A.A.Plugin, M.G.Saliya, T.A.Kostyuk, NTU "KHPI", Kharkiv, Ukraine (2011), 50, p.97.

6. V.S.Gorshkov, V.V.Timashev, V.G.Savel'yev, Methods of Physico-chemical Analysis of Binders, Vysshaya Shkola, Moscow (1981). 